\title{
Combating Diagnostic Delay of Endometriosis in Adolescents via Educational Awareness: A Systematic Review
}

\author{
Cassandra N. Simpson ${ }^{1}$, Christine M. Lomiguen ${ }^{2,} 3$, Justin Chin ${ }^{4,5}$ \\ 1. Obstetrics and Gynecology, Lake Erie College of Osteopathic Medicine, Erie, USA 2. Pathology, Lake Erie College of \\ Osteopathic Medicine, Erie, USA 3. Family Medicine, Millcreek Community Hospital, Erie, USA 4. Medical Education, \\ Lake Erie College of Osteopathic Medicine, Erie, USA 5. Family Medicine, LifeLong Medical Care, Richmond, USA
}

Corresponding author: Christine M. Lomiguen, clomiguen@lecom.edu

\begin{abstract}
Endometriosis occurs in approximately $10 \%$ of adult women worldwide; however, it is commonly under- or misdiagnosed in adolescents. The purpose of this study was to analyze existing scientific literature for reasons for diagnostic delay of endometriosis and to determine how education regarding endometriosis could be improved. An integrative review was conducted based on articles published between December 1980 and December 2020. Suitable articles were identified from the MEDLINE/PubMed databases, using relevant terms. Eligible studies included discussion on potential causes of diagnostic delay of endometriosis in the adolescent population. Data were extracted from eligible publications and qualitative synthesis was used. The 27 articles included in the study revealed several primary reasons for the delay, such as a physician and/or patient knowledge gap, normalization by physician and patient, lack of research, and physician resistance. Strategies to lessen diagnostic delay of endometriosis in adolescents must include integrated actions by educators and healthcare providers to improve health literacy and awareness of common causes of pelvic pain in this age group.
\end{abstract}

Received 05/06/2021 Review began 05/11/2021 Review ended 05/12/2021 Published 05/20/2021

\section{(c) Copyright 2021}

Simpson et al. This is an open access article distributed under the terms of the Creative Commons Attribution License CC-BY 4.0., which permits unrestricted use, distribution, and reproduction in any medium, provided the original author and source are credited.
Categories: Family/General Practice, Medical Education, Obstetrics/Gynecology

Keywords: endometriosis, adolescents, pelvic pain, general gynecology, medical education

\section{Introduction And Background}

Endometriosis is defined as endometrial-like glands or stroma outside of the uterine cavity that leads to an estrogen-dependent chronic inflammatory state. This endometrial-like tissue is classically found on the ovaries, uterine ligaments, and rectovaginal septum [1]. Endometriosis is present in approximately $10 \%$ of adult women worldwide, but the prevalence in adolescent populations has been difficult to quantify; estimates have varied among studies [2]. Endometriosis is the leading cause of chronic pelvic pain and most often presents in adolescents with dysmenorrhea, or acyclic pelvic pain. Endometriosis and its attributable symptoms can greatly affect an adolescent's life, causing absenteeism in school, decreased socialization, and sexual impairment [3]. Characteristics associated with increased risk of endometriosis involve prolonged exposure to estrogen, such as shorter menstrual cycles, early menarche, or late menopause [4], as well as a family history of endometriosis, and Mullerian anomalies [5].

Adolescents may be affected by endometriosis, or early-onset endometriosis, contingent upon the timeline of symptoms and menarche. A unanimous theory regarding the pathogenesis of endometriosis has yet to be elucidated; however, widely accepted theories fall into one of two categories in relation to the origin of ectopic endometrial tissue (Figure 1). One category proposes ectopic endometrial tissue originates in the individual's endometrium. The major theory that falls into this category is the retrograde flow theory, in which it is assumed that retrograde flow of endometrial tissue during menstruation leads to ectopic implantation. Similarly, the benign metastases theory suggests the spread of endometrial tissue can occur through lymphatic and hematogenous channels. Contrarily, the other proposed category suggests tissues outside of the uterus give rise to endometrial-like glands and stroma. For example, the metaplastic theory favors the idea of coelomic epithelium and mesonephric remnants undergoing transformation into ectopic endometrial tissue. Lastly, the progenitor cell theory illustrates the possibility of progenitor cells directly from bone marrow differentiating into ectopic endometrial tissue [1]. 


\section{Cureus}

Origin of Ectopic Endometrial Tissue

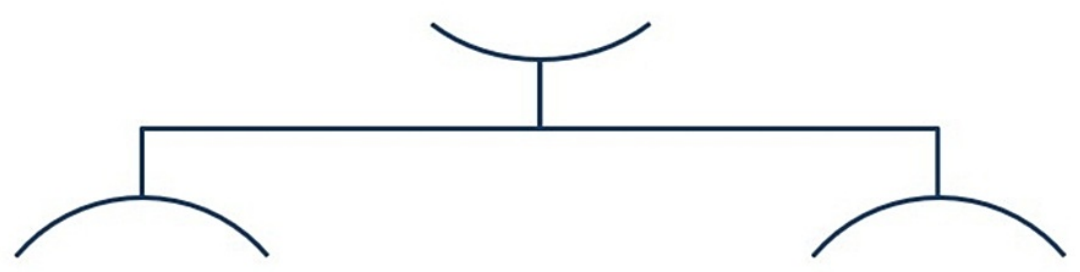

Endometrium

Tissue Outside Uterus

1. Retrograde Flow Theroy

2. Benign Metastases Theory

1. Metaplastic Theory

2. Progenitor Cell Theory
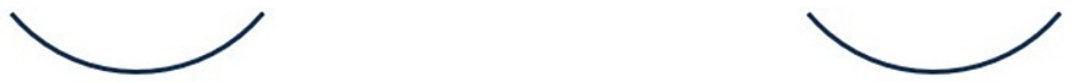

FIGURE 1: Supported Theories of the Pathogenesis of Endometriosis

Furthermore, recent evidence suggests the cause of early-onset endometriosis, defined as presenting prior to menarche, is neonatal uterine bleeding [2]. This process involves the implantation of endometrial progenitor cells into the pelvic cavity. Bleeding can occur in the postnatal period secondary to maternal progesterone withdrawal. These naive endometrial cells can be seeded in the peritoneum, and then become activated during thelarche [5]. Thus, individuals with early-onset endometriosis may experience symptoms prior to menarche [2].

The aim of this review was to assess the major causes of diagnostic delay of endometriosis, specifically in adolescents. Addressing major causes for delay and recognizing how these factors are potentially affected by increased digital education have the potential to mitigate further setbacks in the diagnostic timeline. Moreover, suggestions are included for incorporating information regarding pelvic pain syndromes, such as endometriosis, in formal educational settings for premenarcheal women.

\section{Review}

\section{Methods}

A search was conducted of the National Library of Medicine's MEDLINE/PubMed databases with the intent of finding all articles published in the English language from 1980 to 2020 with "endometriosis" in conjunction with "diagnostic delay" and "adolescent" or "adolescence". Articles identified by this search strategy were read in full and analyzed for relevance. Additionally, corresponding bibliographic reference sections were reviewed for additional studies not found by the previous method. All articles were initially accessed between August 2020 and November 2020. A total of one hundred four (104) articles were reviewed and retrieved independently by the first author. In order to be included, a discussion of potential causes of diagnostic delay of endometriosis in the adolescent population must have been present in the publication. One article was not able to be obtained in full text and was thus excluded. Forty-four (44) articles did not possess relevant information regarding diagnostic delay of endometriosis and were thus excluded. Fifteen (15) articles were excluded due to a lack of information regarding the adolescent population. Lastly, relevant aspects of endometriosis were not discussed in seventeen (17) articles that were ultimately excluded. A total of twenty-seven (27) manuscripts met the criteria and were used in this review (Figure 2). The quality of studies was assessed using National Institutes of Health (NIH) quality assessment tools [6]. Each study was classified as low risk ( $\geqslant 7$ ), moderate risk (5-6), or high risk of bias ( $\leqslant 4)$. 


\section{Cureus}

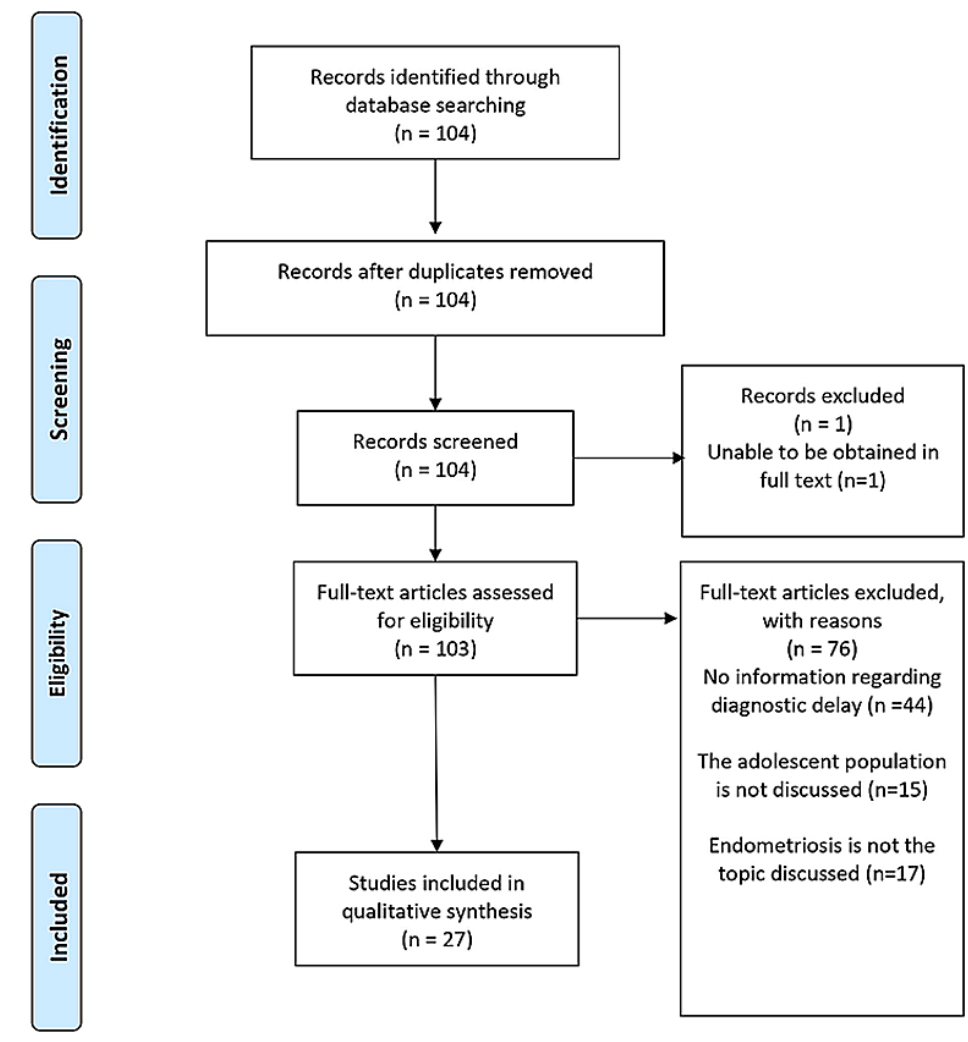

FIGURE 2: PRISMA Flow Chart Indicating the Inclusion of Manuscripts Regarding the Diagnostic Delay of Endometriosis

\section{Results}

A total of twenty-seven (27) articles [5,7-32] were selected to illustrate the different reasons for the diagnostic delay of endometriosis in adolescents. From these 27 articles, thirty-two (32) reasons for the diagnostic delay were extrapolated and classified into one of six categories. The analysis and categorization of the reasons for delay are conveyed in Table 1 .

\begin{tabular}{|c|c|c|c|c|c|c|}
\hline Author/Year & $\begin{array}{l}\text { Publication } \\
\text { Bias }\end{array}$ & $\begin{array}{l}\text { Type of } \\
\text { Study }\end{array}$ & Participants & Age & Cause of Diagnostic Delay & Category \\
\hline $\begin{array}{l}\text { Gubbels et } \\
\text { al., } 2020[5]\end{array}$ & 4 & Review & NA & $\begin{array}{l}10- \\
19\end{array}$ & $\begin{array}{l}\text { Misunderstanding of the complex disease process; } \\
\text { differences in presentation between adolescents } \\
\text { and adults }\end{array}$ & $\begin{array}{l}\text { Physician } \\
\text { knowledge } \\
\text { gap }\end{array}$ \\
\hline $\begin{array}{l}\text { Suvitie et } \\
\text { al., } 2016[7]\end{array}$ & 8 & $\begin{array}{l}\text { Cross- } \\
\text { Sectional } \\
\text { Study }\end{array}$ & 1103 & $\begin{array}{l}15- \\
19\end{array}$ & $\begin{array}{l}\text { Adolescents waited } 3 \text { times longer than adults to } \\
\text { seek treatment for their symptoms }\end{array}$ & $\begin{array}{l}\text { Normalization } \\
\text { by Patient }\end{array}$ \\
\hline $\begin{array}{l}\text { Sachedina } \\
\text { et al., } 2020 \\
\text { [8] }\end{array}$ & 2 & Review & NA & $\begin{array}{l}10- \\
19\end{array}$ & Normalization of dysmenorrhea by a physician & $\begin{array}{l}\text { Normalization } \\
\text { by Physician }\end{array}$ \\
\hline $\begin{array}{l}\text { Pirtea et al., } \\
2020 \text { [9] }\end{array}$ & 1 & Review & NA & $\begin{array}{l}10- \\
19\end{array}$ & Normalization of dysmenorrhea by a physician & $\begin{array}{l}\text { Normalization } \\
\text { by Physician }\end{array}$ \\
\hline $\begin{array}{l}\text { Pirtea et al., } \\
2020 \text { [9] }\end{array}$ & 1 & Review & NA & $\begin{array}{l}10- \\
19\end{array}$ & $\begin{array}{l}\text { Physicians resistant to conduct the laparoscopic } \\
\text { procedure in adolescents }\end{array}$ & $\begin{array}{l}\text { Physician } \\
\text { resistance }\end{array}$ \\
\hline $\begin{array}{l}\text { Sieberg et } \\
\text { al., } 2020 \text { [10] }\end{array}$ & 2 & Review & NA & $\begin{array}{l}10- \\
19\end{array}$ & $\begin{array}{l}\text { Lack of endometriosis research specifically for } \\
\text { adolescent presentation }\end{array}$ & $\begin{array}{l}\text { Lack of } \\
\text { Research }\end{array}$ \\
\hline $\begin{array}{l}\text { Sieberg et } \\
\text { al., } 2020[10]\end{array}$ & 2 & Review & NA & $\begin{array}{l}10- \\
19\end{array}$ & $\begin{array}{l}\text { Lesions in adolescents are usually clear, white, } \\
\text { and/ or yellow-brown. Lesions in adults are usually } \\
\text { black or blue }\end{array}$ & $\begin{array}{l}\text { Physician } \\
\text { knowledge } \\
\text { gap }\end{array}$ \\
\hline
\end{tabular}




\section{Cureus}

\begin{tabular}{|c|c|c|c|c|c|c|}
\hline $\begin{array}{l}\text { Dun et al., } \\
2015 \text { [11] }\end{array}$ & 9 & $\begin{array}{l}\text { Retrospective } \\
\text { Case Series }\end{array}$ & 288 & $\begin{array}{l}10- \\
19\end{array}$ & Presence of atypical lesions & $\begin{array}{l}\text { Physician } \\
\text { knowledge } \\
\text { gap }\end{array}$ \\
\hline $\begin{array}{l}\text { Dun et al., } \\
2015 \text { [11] }\end{array}$ & 9 & $\begin{array}{l}\text { Retrospective } \\
\text { Case Series }\end{array}$ & 288 & $\begin{array}{l}10- \\
19\end{array}$ & $\begin{array}{l}\text { Adolescents may experience different symptoms, } \\
\text { such as vague abdominal discomfort, Gl distress, } \\
\text { and genitourinary symptoms }\end{array}$ & $\begin{array}{l}\text { Physician } \\
\text { knowledge } \\
\text { gap }\end{array}$ \\
\hline $\begin{array}{l}\text { Staal et al., } \\
2016 \text { [12] }\end{array}$ & 7 & $\begin{array}{l}\text { Retrospective } \\
\text { Cohort Study }\end{array}$ & 93 & $>18$ & $\begin{array}{l}\text { Infertility, a symptom not readily recognized in } \\
\text { adolescents, may result in a faster diagnosis in } \\
\text { adults. }\end{array}$ & $\begin{array}{l}\text { Physician } \\
\text { knowledge } \\
\text { gap }\end{array}$ \\
\hline $\begin{array}{l}\text { Shadbolt et } \\
\text { al., } 2013 \text { [13] }\end{array}$ & 7 & Survey & 131 & $\begin{array}{l}16- \\
25\end{array}$ & $\begin{array}{l}\text { Lack of patient knowledge and understanding of } \\
\text { the disease }\end{array}$ & $\begin{array}{l}\text { Patient } \\
\text { Knowledge } \\
\text { Gap }\end{array}$ \\
\hline $\begin{array}{l}\text { Youngster } \\
\text { et al., } 2013 \\
\text { [14] }\end{array}$ & 7 & $\begin{array}{l}\text { Cross- } \\
\text { Sectional } \\
\text { Study }\end{array}$ & 295 & $<18$ & $\begin{array}{l}\text { Unique presentation in adolescents leads to high } \\
\text { rates of misdiagnosis }\end{array}$ & $\begin{array}{l}\text { Physician } \\
\text { knowledge } \\
\text { gap }\end{array}$ \\
\hline $\begin{array}{l}\text { Brosens et } \\
\text { al., } 2013 \text { [15] }\end{array}$ & 5 & $\begin{array}{l}\text { Systematic } \\
\text { Review }\end{array}$ & 437 & $\begin{array}{l}10- \\
21\end{array}$ & $\begin{array}{l}\text { Dysmenorrhea and acyclic menstrual pain are } \\
\text { common complaints that often do not elicit a } \\
\text { further investigation }\end{array}$ & $\begin{array}{l}\text { Normalization } \\
\text { by Physician }\end{array}$ \\
\hline $\begin{array}{l}\text { Brosens et } \\
\text { al., } 2013 \text { [15] }\end{array}$ & 5 & $\begin{array}{l}\text { Systematic } \\
\text { Review }\end{array}$ & 437 & $\begin{array}{l}10- \\
12\end{array}$ & $\begin{array}{l}\text { A differential diagnosis that is focused more on the } \\
\text { gastrointestinal system due to symptoms such as } \\
\text { abdominal pain and Gl dysfunction }\end{array}$ & $\begin{array}{l}\text { Physician } \\
\text { knowledge } \\
\text { gap }\end{array}$ \\
\hline $\begin{array}{l}\text { Santos et } \\
\text { al., } 2012[16]\end{array}$ & 4 & $\begin{array}{l}\text { Retrospective } \\
\text { Analysis }\end{array}$ & 262 & $<20$ & $\begin{array}{l}\text { Resistant to consider this diagnosis in younger } \\
\text { patients }\end{array}$ & $\begin{array}{l}\text { Physician } \\
\text { resistance }\end{array}$ \\
\hline $\begin{array}{l}\text { Pugsley et } \\
\text { al., } 2007 \text { [17] }\end{array}$ & 8 & $\begin{array}{l}\text { Retrospective } \\
\text { Analysis }\end{array}$ & 101 & $>16$ & $\begin{array}{l}\text { Ultrasound is commonly ordered, but only helpful in } \\
\text { diagnosing about } 10 \% \text { of cases }\end{array}$ & $\begin{array}{l}\text { Physician } \\
\text { knowledge } \\
\text { gap }\end{array}$ \\
\hline $\begin{array}{l}\text { Chapron, } \\
2002[18]\end{array}$ & 8 & $\begin{array}{l}\text { Retrospective } \\
\text { Analysis }\end{array}$ & 160 & $\begin{array}{l}19- \\
51\end{array}$ & $\begin{array}{l}\text { Speculum exam allows endometriotic lesions to be } \\
\text { viewed in only } 14.4 \% \text { of patients }\end{array}$ & $\begin{array}{l}\text { Physician } \\
\text { knowledge } \\
\text { gap }\end{array}$ \\
\hline $\begin{array}{l}\text { Seear, } 2009 \\
{[19]}\end{array}$ & 1 & $\begin{array}{l}\text { Qualitative } \\
\text { Survey }\end{array}$ & 20 & $\begin{array}{l}24- \\
55\end{array}$ & Normalization of menstrual pain & $\begin{array}{l}\text { Normalization } \\
\text { by Physician }\end{array}$ \\
\hline $\begin{array}{l}\text { Seear, } 2009 \\
{[19]}\end{array}$ & 1 & $\begin{array}{l}\text { Qualitative } \\
\text { Survey }\end{array}$ & 20 & $\begin{array}{l}24- \\
55\end{array}$ & $\begin{array}{l}\text { Women are often reluctant to disclose menstrual } \\
\text { irregularities }\end{array}$ & $\begin{array}{l}\text { Normalization } \\
\text { by Patient }\end{array}$ \\
\hline $\begin{array}{l}\text { Troyer, } 2007 \\
\text { [20] }\end{array}$ & 7 & Case Study & 1 & 25 & $\begin{array}{l}\text { Adolescents may experience different symptoms, } \\
\text { such as low back and buttock pain, for which } \\
\text { endometriosis is not part of the differential } \\
\text { diagnosis. }\end{array}$ & $\begin{array}{l}\text { Physician } \\
\text { knowledge } \\
\text { gap }\end{array}$ \\
\hline $\begin{array}{l}\text { Ballweg, } \\
2003 \text { [21] }\end{array}$ & 1 & Opinion Piece & NA & NA & $\begin{array}{l}\text { Girls take an average of } 4.67 \text { years to report } \\
\text { symptoms to their doctor }\end{array}$ & $\begin{array}{l}\text { Normalization } \\
\text { by patient }\end{array}$ \\
\hline $\begin{array}{l}\text { ACOG, } 2005 \\
\text { [22] }\end{array}$ & 1 & $\begin{array}{l}\text { Committee } \\
\text { Opinion }\end{array}$ & NA & $\begin{array}{l}10- \\
19\end{array}$ & $\begin{array}{l}\text { Imaging studies, such as ultrasound, and serum } \\
\text { markers, such as CA } 125 \text { can be used to diagnose } \\
\text { endometriosis in adults, but are rarely useful in } \\
\text { diagnosing adolescents }\end{array}$ & $\begin{array}{l}\text { Physician } \\
\text { knowledge } \\
\text { gap }\end{array}$ \\
\hline $\begin{array}{l}\text { Laufer et al., } \\
2003[23]\end{array}$ & 3 & Review & NA & $\begin{array}{l}10- \\
19\end{array}$ & $\begin{array}{l}\text { Adolescents may have subtle signs of } \\
\text { endometriosis on laparoscopy }\end{array}$ & $\begin{array}{l}\text { Physician } \\
\text { knowledge } \\
\text { gap }\end{array}$ \\
\hline $\begin{array}{l}\text { Garcia et } \\
\text { al., } 2003 \text { [24] }\end{array}$ & 7 & Case Study & 1 & 18 & $\begin{array}{l}\text { Delayed diagnosis of underlying congenital } \\
\text { anomaly that leads to endometriosis as a } \\
\text { complication }\end{array}$ & $\begin{array}{l}\text { Physician } \\
\text { knowledge } \\
\text { gap }\end{array}$ \\
\hline \multirow[t]{2}{*}{$\begin{array}{l}\text { De Sanctis } \\
\text { et al., } 2018 \\
\text { [25] }\end{array}$} & 3 & Review & NA & $<25$ & $\begin{array}{l}\text { Lack of standard methods for assessing the } \\
\text { severity of symptoms in adolescents }\end{array}$ & $\begin{array}{l}\text { Lack of } \\
\text { Research }\end{array}$ \\
\hline & & & & & & Physician \\
\hline
\end{tabular}




\section{Cureus}

\begin{tabular}{|c|c|c|c|c|c|c|}
\hline $\begin{array}{l}\text { De Sancis et } \\
\text { al., } 2018[25]\end{array}$ & 3 & Review & NA & $<25$ & $\begin{array}{l}\text { Subtle, atypical lesions that are red or clear instead } \\
\text { of brown are more common in adolescents }\end{array}$ & $\begin{array}{l}\text { knowledge } \\
\text { gap }\end{array}$ \\
\hline $\begin{array}{l}\text { Parasar et } \\
\text { al., } 2013[26]\end{array}$ & 1 & Review & NA & NA & $\begin{array}{l}\text { High cost of diagnosis and treatment in } \\
\text { adolescents }\end{array}$ & $\begin{array}{l}\text { Physician } \\
\text { Resistance }\end{array}$ \\
\hline $\begin{array}{l}\text { Gordts et } \\
\text { al., } 2015 \text { [27] }\end{array}$ & 2 & Review & NA & NA & Mild or complete lack of pelvic pain symptoms & $\begin{array}{l}\text { Physician } \\
\text { knowledge } \\
\text { gap }\end{array}$ \\
\hline $\begin{array}{l}\text { Fong et al., } \\
2017 \text { [28] }\end{array}$ & 9 & $\begin{array}{l}\text { Retrospective } \\
\text { Chart Review }\end{array}$ & 45 & $\begin{array}{l}14- \\
25\end{array}$ & $\begin{array}{l}\text { Cultural reluctance to visit a gynecologist at a } \\
\text { young age }\end{array}$ & $\begin{array}{l}\text { Patient } \\
\text { knowledge } \\
\text { gap }\end{array}$ \\
\hline $\begin{array}{l}\text { Fong et al., } \\
2017 \text { [28] }\end{array}$ & 9 & $\begin{array}{l}\text { Retrospective } \\
\text { Chart Review }\end{array}$ & 45 & $\begin{array}{l}14- \\
25\end{array}$ & $\begin{array}{l}\text { Symptoms are different than adult presentation; } \\
\text { may include dyschezia, dysuria, urgency, hematuria }\end{array}$ & $\begin{array}{l}\text { Physician } \\
\text { knowledge } \\
\text { gap }\end{array}$ \\
\hline $\begin{array}{l}\text { DiVasta et } \\
\text { al., } 2018 \text { [29] }\end{array}$ & 7 & $\begin{array}{l}\text { Cross- } \\
\text { Sectional } \\
\text { Study }\end{array}$ & 402 & $<18$ & $\begin{array}{l}\text { Nausea in conjunction with pelvic pain is a major } \\
\text { symptom in adolescents }\end{array}$ & $\begin{array}{l}\text { Physician } \\
\text { knowledge } \\
\text { gap }\end{array}$ \\
\hline $\begin{array}{l}\text { Shim et al., } \\
2020 \text { [30] }\end{array}$ & 2 & Review & NA & $\begin{array}{l}10- \\
19\end{array}$ & $\begin{array}{l}\text { Infrequent presentation of endometrioma or } \\
\text { infertility, the major symptoms in adults }\end{array}$ & $\begin{array}{l}\text { Physician } \\
\text { knowledge } \\
\text { gap }\end{array}$ \\
\hline $\begin{array}{l}\text { Galczyznski } \\
\text { et al., } 2019 \\
\text { [31] }\end{array}$ & 5 & Review & NA & $\begin{array}{l}11- \\
19\end{array}$ & $\begin{array}{l}\text { Adolescents tend to wait longer to seek } \\
\text { professional help }\end{array}$ & $\begin{array}{l}\text { Normalization } \\
\text { by Patient }\end{array}$ \\
\hline $\begin{array}{l}\text { Martire et } \\
\text { al., } 2020[32]\end{array}$ & 12 & $\begin{array}{l}\text { Retrospective } \\
\text { Observational } \\
\text { Study }\end{array}$ & 270 & $\begin{array}{l}12- \\
20\end{array}$ & Misdiagnosis & $\begin{array}{l}\text { Physician } \\
\text { knowledge } \\
\text { gap }\end{array}$ \\
\hline
\end{tabular}

TABLE 1: Summary of Reasons for Diagnostic Delay of Endometriosis in Adolescents

Six (6) reasons for the diagnostic delay of endometriosis in adolescents were identified through this literature review: four (4) physician-related reasons (knowledge gap, normalization, lack of research, and resistance) and two (2) patient-related reasons (knowledge gap and normalization), with physician

knowledge gap as the most identified reason. The number of articles in each category is conveyed in Table 2.

\begin{tabular}{|c|c|c|}
\hline \multicolumn{2}{|c|}{ Reason for Diagnostic Delay } & Number of Cited Articles \\
\hline \multirow{4}{*}{ Physician-related } & Physician Knowledge Gap & 19 \\
\hline & Normalization by Physician & 4 \\
\hline & Lack of Research & 2 \\
\hline & Physician Resistance & 3 \\
\hline \multirow{2}{*}{ Patient-related } & Patient Knowledge Gap & 2 \\
\hline & Patient Normalization & 4 \\
\hline
\end{tabular}

Each study was individually evaluated for publication using the NIH quality assessment scales. Using these scales, studies were classified as low risk ( $>7)$, medium risk (5-6), or high risk of bias ( $<4)$. The overall risk of publication bias across all studies used was 4.92, indicating a moderate risk of bias. All review articles lacked independent quality ratings of studies that were used. Similarly, all lacked an overall publication bias, ultimately leading to lower scores on the NIH quality assessment scale. Review studies comprised the largest cohort of studies, and therefore remain the greatest risk for bias. 


\section{Discussion}

Patient-Related Causes of Diagnostic Delay

Among the categories determined for causes of diagnostic delay, two placed the cause of delay on the patient seeking treatment. Normalization of dysmenorrhea and other menstrual pain symptoms caused adolescent women to wait three times longer to seek medical treatment than adults with the same symptoms [7].

Similarly, a patient's own knowledge gap may lead to delayed diagnosis. Historically, healthcare providers were the primary sources for learning about endometriosis; however, the rise of the use of the internet has allowed for a more individualized approach to symptom recognition [13]. Comprehensive sexual education through the education system has been shown to advance awareness in both traditional sexual health, such as sexually transmitted infections (STIs) and pregnancy, as well as adjacent topics, such as dating and intimate partner violence, appreciation of sexual diversity, and development of healthy relationships [33]. There lacks, however, a formal curriculum in the United States for adolescent awareness of endometriosis and its symptoms. A pilot program in New Zealand has suggested that an endometriosis-focused curriculum increases awareness of the condition in adolescent students with subsequent earlier presentations to appropriate healthcare providers for clinical assessment, diagnosis, and treatment [34]. However, the expansion of digital education has produced dissatisfaction with learning due to poor internet connection, methods of presentation, and level of participation in class activities. This could ultimately lead to a decrease in adolescent knowledge of health conditions [35].

Physician-Related Causes of Diagnostic Delay

Four categories placed the cause of delay on the physician. Providers may lack proper insight on the presentation of endometriosis in adolescents compared to adults. Gaps in education can ultimately lead to gaps in knowledge and lack of comprehension, resulting in the inability to diagnose or treat certain diseases. Physicians were also shown to have reluctance in including endometriosis as part of their differential diagnosis when patients presented with a chief complaint of severe back pain or gastrointestinal symptoms rather than the standard menstrual symptoms [10,11]. While these are presenting symptoms of an adolescent with endometriosis, many health care providers fail to recognize these symptoms as such. Similarly, patients who reported dyspareunia and dysmenorrhea were found to have a longer delay in diagnosis, than those who denied those symptoms [16]. A lack of research specifically for adolescent endometriosis exists, and ultimately may be ignored as a potential diagnosis. Common symptoms, such as dysmenorrhea, often do not elicit further evaluation by a physician, indicating that symptoms of menstrual pain have been normalized by physicians [15].

Moreover, it is common for physicians to attempt to diagnose endometriosis using an ultrasound machine, or speculum exam, but these methods have not been shown to successfully diagnose adolescents [17]. Laparoscopy, which is a necessary procedure to achieve a definitive diagnosis, is only recommended after the patient's symptoms have failed to subside after medical treatment with non-steroidal anti-inflammatory drugs (NSAIDs) and estrogen/progestin or progestin-only therapy [30]. Physicians may be resistant to perform laparoscopic procedures on adolescents due to the invasiveness and cost of the procedure. However, it is through laparoscopy that the most accurate diagnosis may be made [30].

Endometriosis Education

The CDC outlines current guidelines for formulating a sexual health curriculum utilizing eight Healthy Behavior Outcomes (HBO) in grades pre-kindergarten through 12th grade (Table 3). HBO number eight includes promoting the use of health services to promote sexual health [36]. The result of this review suggests that this category should be broadened to include information regarding menstrual pain and pelvic pain syndromes that could ultimately affect a young woman's life. Adolescents often are unprepared for menarche when their education system fails to teach them about it. These patients are therefore not equipped to properly handle symptoms that may accompany menarche and are unlikely to recognize if symptoms are abnormal. Furthermore, the expansion of digital education has produced dissatisfaction with learning due to poor internet connection, methods of presentation, and level of participation in class activities. This could ultimately lead to a decrease in adolescent knowledge of health conditions [35]. The appropriate use of health services to promote sexual health should encompass the normal and abnormal changes that may present alongside sexual development. 


\section{Cureus}

Healthy Behavior Outcomes (HBO)

HBO 1: Establish and Maintain healthy relationships

HBO 2: Be sexually abstinent

HBO 3: Engage in behaviors that prevent or reduce sexually transmitted disease, including HIV infection

HBO 4: Engage in behaviors that prevent or reduce unintended pregnancy

HBO 5: Avoid pressuring others to engage in sexual behaviors

HBO 6: Support others to avoid or reduce sexual risk behaviors

HBO 7: Treat others with courtesy and respect without regard to their sexuality

HBO 8: Use appropriate health services to promote sexual health

TABLE 3: Center for Disease Control Healthy Behavior Outcomes for Students in PreKindergarten through 12th Grade

\section{Conclusions}

The information in this review is limited by the moderate risk of bias determined using the NIH quality assessment scale. Similarly, there is a risk of misclassification of reasons for the diagnostic delay. Future studies can suggest specific educational strategies to increase both physician, patient, and adolescent population knowledge regarding endometriosis to address the identified categories of diagnostic delay by lessening knowledge gaps, preventing normalization, decreasing resistance, and encouraging additional research.

Ultimately, the diagnostic delay of endometriosis highlights the need for increased health literacy, specifically the education of young females with respect to common pelvic pain syndromes. Gynecologists, as well as primary care providers and health educators, play a key role in mitigating the effect of endometriosis on an adolescent's life, and therefore, must be aware of all possible presenting symptoms.

\section{Additional Information}

\section{Disclosures}

Conflicts of interest: In compliance with the ICMJE uniform disclosure form, all authors declare the following: Payment/services info: All authors have declared that no financial support was received from any organization for the submitted work. Financial relationships: All authors have declared that they have no financial relationships at present or within the previous three years with any organizations that might have an interest in the submitted work. Other relationships: All authors have declared that there are no other relationships or activities that could appear to have influenced the submitted work.

\section{References}

1. Kumar V, Abbas AK, Aster JC: Robbins and Cotran Pathologic Basis of Disease . W.B. Saunders Company, Philadelphia, PA; 2014.

2. Gargett CE, Schwab KE, Brosens JJ, Puttemans P, Benagiano G, Brosens I: Potential role of endometrial stem/progenitor cells in the pathogenesis of early-onset endometriosis. Mol Hum Reprod. 2014, 20:591-8. 10.1093/molehr/gau025

3. Benagiano G, Guo SW, Puttemans P, Gordts S, Brosens I: Progress in the diagnosis and management of adolescent endometriosis: an opinion. Reprod Biomed Online. 2018, 36:102-14. 10.1016/j.rbmo.2017.09.015

4. Nnoaham KE, Webster P, Kumbang I, Kennedy SH, Zondervan KT: Is early age at menarche a risk factor for endometriosis? A systematic review and meta-analysis of case-control studies. Fertil Steril. 2012, 98:702712.e6. 10.1016/j.fertnstert.2012.05.035

5. Gubbels A, Spivack L, Lindheim SR, Bhagavath B: Adolescent endometriosis. Obstet Gynecol Surv. 2020, 75:483-96. 10.1097/OGX.0000000000000808

6. National Institutes of Health. Study Quality Assessment Tools . (2020). Accessed: December 22, 2020: https://www.nhlbi.nih.gov/health-topics/study-quality-assessment-tools.

7. Suvitie PA, Hallamaa MK, Matomäki JM, Mäkinen JI, Perheentupa AH: Prevalence of pain symptoms suggestive of endometriosis among Finnish adolescent girls (TEENMAPS Study). J Pediatr Adolesc Gynecol. 2016, 29:97-103. 10.1016/.jpag.2015.07.001

8. Sachedina A, Todd N: Dysmenorrhea, endometriosis and chronic pelvic pain in adolescents . J Clin Res Pediatr Endocrinol. 2020, 12:7-17. 10.4274/jcrpe.galenos.2019.2019.S0217

9. Pirtea P, de Ziegler D, Ayoubi JM: Diagnosing endometriosis in adolescents: ultrasound is a game changer . Fertil Steril. 2020, 114:967-8. 10.1016/j.fertnstert.2020.07.039 
10. Sieberg CB, Lunde CE, Borsook D: Endometriosis and pain in the adolescent- striking early to limit suffering: a narrative review. Neurosci Biobehav Rev. 2020, 108:866-7. 10.1016/j.neubiorev.2019.12.004

11. Dun EC, Kho KA, Morozov VV, Kearney S, Zurawin JL, Nezhat CH: Endometriosis in adolescents. JSLS. 2015, 19:e2015.00019. 10.4293/JSLS.2015.00019

12. Staal AH, van der Zanden M, Nap AW: Diagnostic delay of endometriosis in the Netherlands. Gynecol Obstet Invest. 2016, 81:321-4. 10.1159/000441911

13. Shadbolt NA, Parker MA, Orthia LA: Communicating endometriosis with young women to decrease diagnosis time. Health Promot J Austr. 2013, 24:151-4. 10.1071/HE12915

14. Youngster M, Laufer MR, Divasta AD: Endometriosis for the primary care physician. Curr Opin Pediatr. 2013, 25:454-62. 10.1097/MOP.0b013e3283628092

15. Brosens I, Gordts S, Benagiano G: Endometriosis in adolescents is a hidden, progressive and severe disease that deserves attention, not just compassion. Hum Reprod. 2013, 28:2026-31. 10.1093/humrep/det243

16. Santos TM, Pereira AM, Lopes RG, Depes Dde B: Lag time between onset of symptoms and diagnosis of endometriosis. Einstein (Sao Paulo). 2012, 10:39-43. 10.1590/s1679-45082012000100009

17. Pugsley Z, Ballard K: Management of endometriosis in general practice: the pathway to diagnosis . Br J Gen Pract. 2007, 57:470-6.

18. Chapron C, Dubuisson J-B, Pansini V, et al.: Routine clinical examination is not sufficient for diagnosing and locating deeply infiltrating endometriosis. J Am Assoc Gynecol Laparosc. 2002, 9:115-9. 10.1016/s10743804(05)60117-x

19. Seear K: The etiquette of endometriosis: stigmatisation, menstrual concealment and the diagnostic delay . Soc Sci Med. 2009, 69:1220-7. 10.1016/j.socscimed.2009.07.023

20. Troyer MR: Differential diagnosis of endometriosis in a young adult woman with nonspecific low back pain . Phys Ther. 2007, 87:801-10. 10.2522/ptj.20060141

21. Ballweg ML: Big picture of endometriosis helps provide guidance on approach to teens: comparative historical data show endo starting younger, is more severe. J Pediatr Adolesc Gynecol. 2003, 16:21-6. 10.1016/s1083-3188(03)00063-9

22. American College of Obstetricians and Gynecologists: ACOG Committee Opinion. Number 310, April 2005. Endometriosis in adolescents. Obstet Gynecol. 2005, 105:921-7. 10.1097/00006250-200504000-00058

23. Laufer MR, Sanfilippo J, Rose G: Adolescent endometriosis: diagnosis and treatment approaches . J Pediatr Adolesc Gynecol. 2003, 16:3-11. 10.1016/s1083-3188(03)00066-4

24. García Peñalver C, Marín Palazón M, Verger Kuhnke AB: Acute urine retention due to herlyn-WernerWunderlinch syndrome. (Article in Spanish). Arch Esp Urol. 2019, 72:530-4.

25. de Sanctis V, Matalliotakis M, Soliman AT, Elsefdy H, Di Maio S, Fiscina B: A focus on the distinctions and current evidence of endometriosis in adolescents. Best Pract Res Clin Obstet Gynaecol. 2018, 51:138-50. 10.1016/j.bpobgyn.2018.01.023

26. Parasar P, Ozcan P, Terry KL: Endometriosis: epidemiology, diagnosis and clinical management. Curr Obstet Gynecol Rep. 2017, 6:34-41. 10.1007/s13669-017-0187-1

27. Gordts S, Puttemans P, Gordts S, Brosens I: Ovarian endometrioma in the adolescent: a plea for early-stage diagnosis and full surgical treatment. Gynecol Surg. 2015, 12:21-30. 10.1007/s10397-014-0877-X

28. Fong YF, Hon SK, Low LL, Lim Mei Xian K: The clinical profile of young and adolescent women with laparoscopically diagnosed endometriosis in a Singapore tertiary hospital. Taiwan J Obstet Gynecol. 2017, 56:181-3. 10.1016/j.tjog.2016.07.013

29. DiVasta AD, Vitonis AF, Laufer MR, Missmer SA: Spectrum of symptoms in women diagnosed with endometriosis during adolescence vs adulthood. Am J Obstet Gynecol. 2018, 218:324.e1-324.e11. 10.1016/j.ajog.2017.12.007

30. Shim JY, Laufer MR: Adolescent endometriosis: an update. J Pediatr Adolesc Gynecol. 2020, 33:112-9. 10.1016/j.jpag.2019.11.011

31. Gałczyński K, Jóźwik M, Lewkowicz D, Semczuk-Sikora A, Semczuk A: Ovarian endometrioma - a possible finding in adolescent girls and young women: a mini-review. J Ovarian Res. 2019, 12:104. 10.1186/s13048019-0582-5

32. Martire FG, Lazzeri L, Conway F, et al.: Adolescence and endometriosis: symptoms, ultrasound signs and early diagnosis. Fertil Steril. 2020, 114:1049-57. 10.1016/j.fertnstert.2020.06.012

33. Goldfarb ES, Lieberman LD: Three decades of research: the case for comprehensive sex education . J Adolesc Health. 2021, 68:13-27. 10.1016/j.jadohealth.2020.07.036

34. Bush D, Brick E, East MC, Johnson N: Endometriosis education in schools: A New Zealand model examining the impact of an education program in schools on early recognition of symptoms suggesting endometriosis. Aust N Z J Obstet Gynaecol. 2017, 57:452-7. 10.1111/ajo.12614

35. Sarwar H, Akhtar H, Naeem MM, et al.: Self-reported effectiveness of e-learning classes during COVID-19 pandemic: a nation-wide survey of Pakistani undergraduate dentistry students. Eur J Dent. 2020, 14:S34-43. $10.1055 / \mathrm{s}-0040-1717000$

36. Centers for Disease Control and Prevention. Health Education Curriculum Analysis Tool (HECAT) . (2021). Accessed: February 12, 2021: https://www.cdc.gov/healthyyouth/hecat/index.htm. 